Portland State University

PDXScholar

$5-1-1990$

\title{
United States Regional History as an Instructional Field: The Practice of College and University History Departments
}

Carl Abbott

Portland State University, d3ca@pdx.edu

Follow this and additional works at: https://pdxscholar.library.pdx.edu/usp_fac

Part of the Urban Studies and Planning Commons

Let us know how access to this document benefits you.

\section{Citation Details}

Abbott, C. United States Regional History as an Instructional Field: The Practice of College and University History Departments. The Western Historical Quarterly, Vol. 21, No. 2 (May, 1990), pp. 197-217.

This Article is brought to you for free and open access. It has been accepted for inclusion in Urban Studies and Planning Faculty Publications and Presentations by an authorized administrator of PDXScholar. Please contact us if we can make this document more accessible: pdxscholar@pdx.edu. 


\title{
United States Regional History as an Instructional Field: The Practice of College and University History Departments
}

\author{
Carl Abbott
}

$\mathrm{O}$ ne of the recurring questions about the practice of American history is the outlook for regionally-based scholarship and teaching. Within a larger field, whose practitioners also divide themselves by periods and topics of specialization, American regional history has sometimes seemed in precarious straits. From U. B. Phillips to C. Vann Woodward and Eugene Genovese, southern historians have responded by repeatedly arguing the uniqueness of their region's heritage and character within the national experience. ${ }^{1}$ Western historians have faced a different problem. Their most common interpretive model views the West, or the westward frontier, as the forerunner of national change and the epitome of the national character- "the most American part of America," as James Bryce put it, five years before Frederick J. Turner's famous essay on the frontier. ${ }^{2}$ The more we stretch the history of the West into our present century, the more its story blends into the general history of the nation.

As part of a larger interest in region as a category of analysis in American social science, I conducted a survey of regional history as a postsecondary instructional field. In part, the survey was designed to explore aspects of professional practice that have not been systematically investigated for a number of years. ${ }^{3}$ In addition, it is intended to create an empirical information base for analyzing the place of regional history within the evolving discipline of American historical studies.

Carl Abbott is professor of Urban Studies and Planning at Portland State University. $\rightarrow$ U. B. Phillips, "The Central Theme of Southern History," American Historical Review, 34 (October 1928), 30-43; C. Vann Woodward, The Burden of Southern History (Baton Rouge, 1960); Eugene D. Genovese, The Political Economy of Slavery (New York, 1965) and The World the Slaveholders Made (New York, 1969).

${ }^{2}$ James Bryce, The American Commonwealth, vol. 2 (1910; New York,1912): 892.

$\rightarrow$ W. N. Davis, Jr., "Will the West Survive as a Field in American History? A Survey Report," Mississippi Valley Historical Review, 50 (March 1964), 672-85; Elliott West, "Cowboys and Indians and Artists and Liars and Schoolmarms and Tom Mix: New Ways to Teach the American West," in Essays on Walter Prescott Webb and the Teaching of History, ed. "Dennis Reinhartz and Stephen Maizlish (College Station, TX, 1985): Monroe Billington, “College Courses in Southern History," Journal of Southern History, 30 (February 1964), 48-57. 
The body of the essay presents the findings in detail. The data were gathered and analyzed without emphasis on any particular region. The results, however, are of special interest to readers of this journal, for they show western history as a field in creative transition. Twenty-five years ago, results of a similar survey were published under the heading, "Will the West survive as a field in American history?" Obviously, there was concern about the viability of western history. It now appears that we should rewrite the question: How will we recognize the rapidly evolving field of western history by the start of the next century?

The history of the United States can be viewed as a sequential process of regional development marked by a persistent tension between regional cultures and economic interests and integrative national institutions and values. For the nation's first century, regional differences were a central issue of national politics. ${ }^{4}$ Region in the twentieth century has remained an important explanatory variable for political behavior. ${ }^{5}$ Recent phenomena, such as the political competition during the Sagebrush Rebellion, or competition between the Sunbelt and Rustbelt, show the continuing ability of regional location and interest to shape relationships between citizens and their national government. ${ }^{6}$

American cultural studies also focus substantial attention on the regional differentiation of everyday life. Specialists have used vernacular architecture, town layout, language, religion, and other expressions of culture and custom to trace the early emergence, expansion, and survival of distinct cultural regions. ${ }^{7}$ Summary studies on the phenomenon of region have appeared in both sociology and geography. Joel Garreau's study of The Nine 1933).

4 Frederick Jackson Turner, The Significance of Sections in American History (New York,

${ }^{5}$ Daniel Elazar, American Federalism: The View from the States (New York, 1972); Ira Sharkansky, Regionalism in American Politics (Indianapolis, 1970); Richard F. Bensil, Sectionalism and American Political Development, 1880-1980 (Madison, WI, 1984).

${ }^{6}$ Robert Jay Dilger, The Sunbelt/Snowbelt Controversy: The War Over Federal Funds (New York, 1982); Peter Wiley and Robert Gottlieb, Empires of the Sun: The Rise of the New American West (New York, 1982); Patricia Nelson Limerick, Legacy of Conquest: The Unbroken Past of the American West (New York, 1987), 46-48, 134-75.

7 For examples, see Henry Glassie, Pattern in the Material Folk Culture of the Eastern United States (Philadelphia, 1968); Fred Kniffen, "Foll $\rightarrow$ ousing: Key to Diffusion," Annals of the Association of American Geographers, 55 (December 1965), 549-77; Peirce F. Lewis, "Common Houses: Cultural Spoor,"' Landscape, 19 (January 1975), 1- $\rightarrow$ Edward T. Price, "Central Courthouse Square in the American County Seat," Geographical Review, 58 (January 1968), 29-60; Hans Kurath and Raven I. McDavid, Jr., The Pronunciation of English in the Atlantic States: Based Upon The Collections of the Linguistic Atlas of the Eastern United States (Ann Arbor, MI, $19 r \rightarrow$ Wilbur Zelinsky, "An Approach to the Religious Geography of the United States: Patterns of Church Membership in 1952," Annals of the Association of American Geographers, 51 (June 1961), 139 $\rightarrow$ James R. Shortridge, "Patterns of Religion in the United States," Geographical Review, 66 (October 1976), 420-34. 
Nations of North America stands as a best-selling popular effort to explore the same question of persisting regional differences and allegiances. ${ }^{8}$

As a field of academic instruction in American colleges and universities, regional history dates to the last decade of the nineteenth century. The Johns Hopkins University reportedly offered the first university course on the history of the South in 1896. The first such course outside the South appeared at the University of Chicago in 1906. The definition of western history as a teaching field was contemporaneous; the young and ambitious Frederick Jackson Turner offered the first such course at the University of Wisconsin in 1895-1896. ${ }^{9}$

Nearly a century later, regional history remains an active academic enterprise. Books on regional history have long been a specialty of leading university presses, including Yale, North Carolina, Louisiana State, Texas, Oklahoma, and Nebraska. New book series announced in the 1980s cover the history of the twentieth-century West, the South, New England, and the Middle West. Journals of regional history and regional studies include the Journal of Southern History, Perspectives on the South, Western Historical Quarterly, Pacific Historical Review, Pacific Northwest Quarterly, Montana The Magazine of Western History, Journal of the Southwest, The Old Northwest, Great Plains Quarterly, and New England Quarterly. Historians can attend meetings of regionally based historical organizations, participate in conferences on regional history, and read new "state of the art" volumes collecting historiographic essays or current historical research on regions from Chesapeake Bay to the Pacific Northwest. ${ }^{10}$

${ }^{8}$ Raymond D. Gastil, Cultural Regions of the United States (Seattle, 1975); Wilbur Zelinsky, The Cultural Geography of the United States (Englewood Cliffs, 1973); John F. Rooney, Jr., Wilbur Zolinsky, and Dean R. Louder, eds. This Remarkable Continent: An Atlas of American and Canadian Society and Culture (College Station, TX, 1982); Joel Garreau, The Nine Nations of North America (Boston, 1981). The basis of current interest in regional patterns is discussed in Richard M. Brown, "The New Regionalism in America, 1970-1981," in Regionalism and the Pacific Northwest, ed. William G. Robbins, Robert J. Frank, and Richard E. Ross (Corvallis, OR, 1983), 37-96.

${ }^{9}$ Billington, "College Courses in Southern History," 48-57; Ray Allen Billington, Frederick Jackson Turner: Historian, Scholar, Teacher (New York, 1973), 135.

${ }_{10}$ Titles from the last ten years include Lois Green Carr, Philip D. Morgan, and Jean B. Russo, eds., Colonial Chesapeake Society (Chapel Hill, NC, 1988); Thad W. Tate and David L. Ammerman, eds., The Chesapeake in the Seventeenth Century: Essays on Anglo-American Society (Chapel Hill, NC, 1979); J. Morgan Kousser and James M. McPherson, eds., Region, Race, and Reconstruction: Essays in Honor of C. Vann Woodward (New York, 1982); John B. Boles and Evelyn T. Nolen, eds., Interpreting Southern History: Historiographic Essays in Honor of Sanford W. Higginbotham (Baton Rouge, 1987); David C. Klingaman and Richard K. Vedder, Essays on the Economy of the Old Northwest (Athens, OH, 1987); James A. Madison, ed., Heartland: Comparative Histories of the Midwestern States (Bloomington, IN, 1988); Frederick C. Luebke, ed., Ethnicity on the Great Plains (Lincoln, NE, 1980); Roger L. Nichols, American Frontier and Western Issues: A Historiographical Review (Westport, CT, 1986); Jerome O. Steffen, ed., The American West: New Perspectives, New Dimensions (Norman, OK, 1979). Gerald Nash and Richard 
Despite its roots, however, regional history occupies an ambiguous position within the larger field of United States history. Since the late 1950s, systematic revisionism that applies the approaches and insights of a wide range of social sciences to key issues of social and political change has revolutionized the field. ${ }^{11}$ Much of the intellectual excitement in American history has involved the definition, or redefinition, of thematic fields such as social history, family history, or urban history, and the analysis of processes such as class formation, labor force socialization, or the definition of gender roles. The usual arenas for testing hypotheses are specific localities, or the nation as a whole, rather than traditional multi-state regions. Important summary volumes on historical writing about the United States have been organized around periods or thematic fields, rather than regions. ${ }^{12}$

These trends within history reflect parallel changes in other social sciences. After World War II, the academic respectability of regional analysis was called into question by its strong identification with political and reform programs of the 1930s and 1940s, leaving a 1951 symposium volume on Regionalism in America as something of a high watermark, rather than a foundation for new work. ${ }^{13}$ The area studies tradition in geography has struggled since the 1950s to hold its own against a newer emphasis on general theories of spatial interaction. ${ }^{14}$ Regional analysis largely disappeared from sociology journals and classrooms from 1950 to $1980 .{ }^{15} \mathrm{~A}$ recent revival of interest in regional differentiation has been keyed by the importation

Etulain, eds., The Twentieth Century West: Historical Interpretations (Albuquerque, 1989); Edwin R. Bingham and Glen A. Love, eds., Northwest Perspectives: Essays on the Culture of the Pacific Northwest (Seattle, 1979); G. Thomas Edwards and Carlos Schwantes, eds., Experiences in a Promised Land (Seattle, 1986).

$\rightarrow$ Allan Bogue, "Systematic Revisionism and a Generation of Ferment in American History," Journal of Contemporary History, 21 (April 1986), 135-62.

${ }^{12}$ John Higham, ed., The Reconstruction of American History (New York, 1962); Herbert J. Bass, ed., The State of American History (Chicago, 1970); George A. Billias and Gerald Grob, eds., American History: Retrospect and Prospect (New York, 1971); Michael Kammen, The Past Before Us: Contemporary History Writing in the United States (Ithaca, NY, 1980).

${ }^{13}$ Merrill Jensen, ed., Regionalism in America (Madison, WI, 1951). Also see Michael O'Brien, The Idea of the American South, 1920-1941 (Baltimore, 19: $\rightarrow$ David Goldfield, "The New Regionalism," Journal of Urban History, 10 (February 1984), 171-86.

$\rightarrow$ William Pattison, "The Four Traditions of Geography," Journal of Geography, 63 (May 1964), 211- $\rightarrow$ Edward Taaffe, "The Spatial View in Context," Annals of the Association of American Geographers, 64 (March 1974), 1-16. Changes within the field of geography can be traced in anthologies such as Saul B. Cohen, ed., Problems and Trends in American Geography (New York, 1967); Wayne K. D. Davies, ed., The Conceptual Revolution in Geography (London, 1972); Mark Billings, Derek Gregory, and Ron Martin, eds., Recollections of a Revolution: Geography as a Spatial Science (New York, 1984).

${ }^{15}$ John Shelton Reed, "Whatever Became of Regional Sociology," in One South: An Ethnic Approach to Regional Culture, by John Shelton Reed (Baton Rouge, 1982), 33-44. 
of world-system theory from abroad, rather than by rediscovery of American sociological traditions. There was a similar trend in political science, whose regionally-based journals were carefully renamed to demonstrate their interest in general issues and processes.

During the spring of 1988 , I sent questionnaires to the chairs of fivehundred departments of history in U. S. colleges and universities listed in the 1987-1988 edition of the American Historical Association's Guide to Departments of History. Utilizing standard mail-survey procedures, I followed the first mailing with a postcard reminder at two weeks and sent a second questionnaire to nonresponding departments at five weeks. ${ }^{16}$ Seeking the fine line between an increased response rate and annoyed colleagues, I omitted the recommended third follow-up. A total of 62 percent, or 309 departments, responded, well within the expected 60-70 percent return rate.

Comparison of the geographical distribution of respondents with the locations of all surveyed departments provides a check on the representativeness of the returns. As Table 1 indicates, the responses slightly overrepresent the north central and western states and underrepresent the Northeast. Because northeastern schools, as a group, are somewhat less likely than others to teach regional courses, the aggregate results probably overstate slightly the prevalence of such courses. However, the relatively close match for all parts of the country supports the validity of the substantive findings.

The questionnaire sought three types of information. First, it asked basic questions on the extent of regional offerings, including the regions treated and course titles. Second, it asked for institutional "demographics," with questions about types of degree offerings, location, size, and similar characteristics. Third, it asked for specific information about each regional course, including levels of interest, interpretive themes, and background of instructor.

A total of 187 schools, or 60.5 percent of the respondents, identified regional history offerings. Ninety-six of these schools offer courses on a single region, sixty-eight on two regions, sixteen on three regions, and three on four, or more, regions.

The propensity to offer at least one regional course can be analyzed by institutional characteristics (Table 2). The proportion of students coming from within state does not show a statistically strong relationship with regional course offerings. As might be expected, however, the likelihood of such course offerings does increase with size and with the presence of graduate programs. Public institutions report a much greater likelihood of offering regional history than do private colleges and universities. Schools

${ }^{16}$ The survey adapted procedures in Don A. Dillman, Mail and Telephone Surveys: The Total Design Method (New York, 1978). 
west of the Mississippi River and south of the Mason-Dixon line and Ohio River offer regional courses much more frequently than do schools in the greater Northeast. Given the historic balance between the wealthy and culturally assertive national core and its subordinated periphery, and the ability of that core to define its own regional characteristics as "national" traits, it is scarcely surprising to find there a relatively limited awareness and interest in regional differences. ${ }^{17}$

Among the relationships in Table 2, it is possible that the higher frequency of regional offerings by public schools might be a product of their larger average size, rather than of characteristic curricular choices. If the data are controlled for size, the public/private difference is reduced for midsized universities enrolling 5,000 to 20,000 students. However, the public/private difference remains substantial for larger and smaller institutions (Table 3).

In explaining the presence, or absence, of regional courses in their curricula, two schools commented on increasing student interest, and four stated plans to offer additional courses. According to one large state university in the West, "While some regional courses have dropped in interest, others, especially dealing with ethnic and gender topics, have more than taken their place." Several other schools reported that, in place of explicitly regional courses, they teach state or local history with a sense of regional context and change. The most common reasons for an absence of regional courses revolved around scarcities of resources. Eleven departments reported dropping regional courses after faculty retirements. Twenty-one referred to their small size, service role, or lack of interested faculty. Several others reported that they allocated available faculty to state history, rather than regional history.

A final group of departments commented that regional history is professionally uninteresting within the context of the 1980s. Seven departments prefer to emphasize social trends, or specific groups, rather than regions. Three others believe that regional history is out of step with the development of the profession. As one large middle western university commented, " $[R]$ egionalism - as conceived in this questionnaire-is no longer a major issue concerning professional historians."

It is no surprise that the West and South are, by far, the most popular regions for regular course coverage (Table 4). The Southwest, with its clearly

17 All four of these relationships are significant at the .005 level of probability. Statistical significance or probability level refers to the likelihood that a particular distribution of values might occur by chance in the absence of differences among the population being sampled or the cases being analyzed. A distribution that is significant at .05 probability might be expected to occur by chance one time out of twenty. A distribution significant at .01 might be expected to occur by chance one time out of a hundred. 
identified ethnic character, distinctive landscape, and rich historiography, stands out as the most popular subregion, followed by the Pacific Northwest, the Great Plains, and New England. The list also includes six regions specified within an open-ended "other" category-Appalachia, the Ozarks, the Tennessee Valley, colonial Louisiana, the North Pacific, and the Sunbelt.

As Table 4 also indicates, there is a discrepancy between the direct report of regional coverage and patterns of coverage, as shown by course titles. Two factors appear to be at work. First, several departments reported that they treated a particular region (e.g., the Middle States), but listed either a general course title (e.g., Colonial America), a city history course, or a state history course. Although the author of this survey has, himself, taught a state history course and published a comprehensive state history, single-state courses do not meet the definition of regional history adopted for this analysis and are omitted from the second column of Table 4. Second, a number of departments double-counted, within the terms of this study, by reporting a course or sequence on the American Frontier and also reporting specific subregions, such as the Middle West, that are covered within the sequence. Again, these overlapping listings do not appear in column two. The analysis of specific regional sets of courses, therefore, focuses on the regions for which the general data appear to reflect individual course offerings-West, South, Southwest, Pacific Northwest, Great Plains, and New England. Information on New England in Tables 5 and 6 should also be treated with caution.

The data in Table 5 indicate that institutional characteristics make little difference in the propensity to offer specific regional courses. Several of the individual deviations can be explained by the general characteristics of schools in particular regions, such as the relatively limited number of small or private colleges in the Plains states and Southwest and the tendency of New England schools to attract large numbers of students from outside the region. When the offerings are aggregated for ease of analysis into those dealing with the South, Southwest, West/Frontier, and all other regions, none of the relationships between regional coverage and institutional characteristics are statistically significant.

We can also analyze the relationship between the regional locations of colleges and universities and their tendency to offer courses on their own region and on other regions (Table 6). The results hold relatively few surprises. As expected, subregional courses are taught almost exclusively in that regional core or its bordering states. Western history is taught outside the West, and southern history outside the South, in nearly the same proportions ( 25 percent and 24 percent, respectively). Somewhat puzzling is the high regional interest in Northwest history (79 percent of responding Northwest schools), compared with the history of the Southwest (41 percent of southwestern schools), especially given the salience of current policy issues 
relating to the ethnic dimensions of the Southwest. All of the Southwest history courses outside the regional core are in the southwestern fringe states of Nevada, Colorado, Oklahoma, Kansas, Arkansas, and Louisiana. It may also be somewhat surprising that only 68 percent of southern colleges and universities teach southern history courses. If the South is subdivided, however, the proportion increases to 75 percent in the Confederate states and drops to 41 percent for the border states.

In addition to department-level data, the survey also elicited usable information about 432 individual courses. The number is considerably higher than the total for regions covered by the different schools (as reported in Table 4), because one institution may have reported two or more courses dealing with the same region-Old South and New South, for example. For the analysis in this section, each such course is treated as a separate case.

To facilitate statistical testing of differences among regional categories, the courses, in most cases, have been grouped as South, West/Frontier, and Other. ${ }^{18}$ There are no significant differences among the three groups of courses in average enrollment or in the propensity to offer the courses for graduate, versus undergraduate, credit. There is a weak relationship (significant at .12) between the course groupings and changing levels of student interest. As Table 7 indicates, there may be a slight tendency toward increasing interest in courses on the West and a somewhat greater increase of interest in courses on the smaller subregions. Finally, there is a pronounced difference in the length of time that different sets of courses have been offered (Table 8 ). The West/Frontier is clearly the most established region in college and university curricula, while a large proportion of "other" courses have been implemented in the 1980s. This pattern may reflect a widening of student interest, as suggested above, or an impulse toward experimentation on the part of instructors. It is important to note that the survey did not obtain systematic information on regional courses that may have been deleted in the last decade. However, specific comments suggest that the greatest erosion in western or frontier history is a result of unreplaced faculty retirements. This scattered evidence supports an interpretation of western/frontier history as an "aging" field of instruction, a situation that simultaneously creates problems and raises possibilities.

${ }^{18}$ See Table 7. Chi Square is a standard test used with contingency tables that divide each variable into two or more categories. The value of Chi Square can be used to determine the statistical significance of the relationship between the two variables-that is, the probability that a given distribution of frequencies might appear by chance. Large differences between the observed and expected frequencies in each cell of a table yield large values for Chi Square and, consequently, low probability levels. 
The survey did seek systematic data on the faculty members who currently teach regional courses. ${ }^{19}$ As Table 9 indicates, western/frontier courses are most likely to have been taught by the same instructor for more than a decade. If Table 9 is reduced to a two-by-two table that cross-tabulates West and All Other against 1-10 years and $10+$ years, the significance level is reduced from .05 to .025 . This evidence on stablity among instructors is paralleled by the relationship between regional specialty and age of instructor, which shows a disproportionate number of western history instructors over age 55 (Table 10). It is also possible to compare the age of teachers of western/frontier, southern, and southwestern courses, as reported in the survey, with the year of highest earned degree for faculty claiming the same areas of specialization in the AHA Guide to Departments of History. Faculty with expertise or interest in the West are somewhat older in both calendar age and academic generation than those specializing in the South (Table 11). Specialists in the Southwest or Spanish Borderlands appear somewhat younger in the AHA data, but not in the survey data.

Additionally, the survey and AHA Guide both help to measure the extent to which teachers and/or specialists in a particular region received their highest degrees from universities in the same region (Table 12). Specialists in the Southwest and Great Plains are most likely to have done their graduate work in the same region. Specialists in the more comprehensive regions of South and West show a moderate 60-40 tilt toward graduate training in their region of interest. Courses on New England and the Great Plains rely heavily on instructors with graduate training outside each region.

The survey asked respondents to mark the states covered by each course on a blank map. Lists of states or maps were offered for approximately 40 percent of the courses. The overlap of "frontier" courses and sequences with regionally defined "West" or "Trans-Mississippi West" courses makes it impossible to use the maps to define a meaningful "historians' West." In contrast, the results show substantial clarity about the core of the South as coterminous with the Confederacy (See Map), although the omission of Florida and Texas, in several cases, is somewhat surprising. The inclusion of border states was problematic. Kentucky was essentially treated as part of the southern core. West Virginia made slightly more than half the lists, Maryland, Missouri, and Oklahoma slightly less than half.

The landscape of the Great Plains also provides the basis for a consensus on regional definition (See Map). Only one course out of seven extends coverage from the plains themselves to the prairie states between the Missouri and Mississippi rivers. course.

19 There is some double counting of instructors responsible for more than one reported 


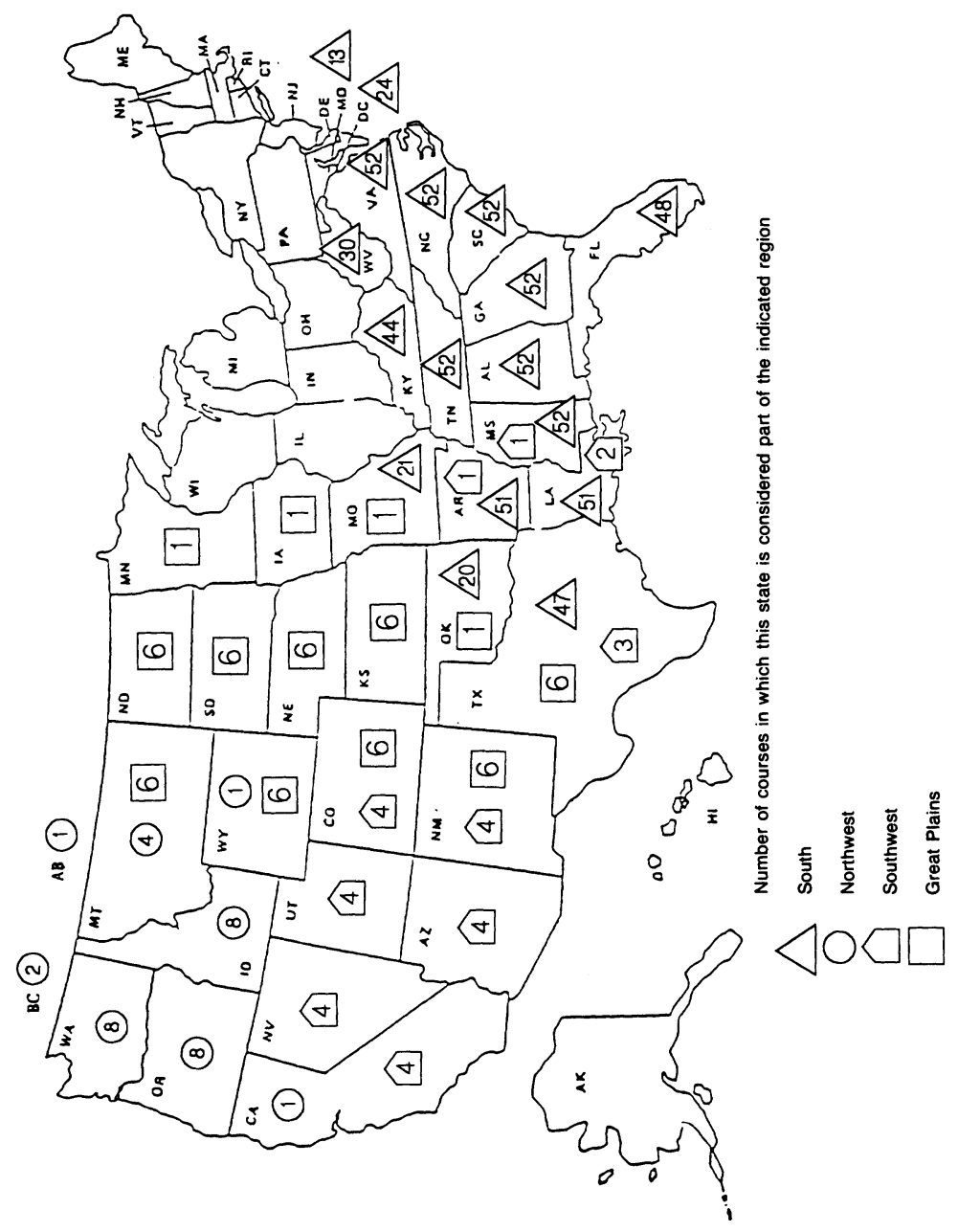


Northwest and Southwest are more loosely defined. With the Northwest, the question is whether to focus tightly on the northern Pacific raincoast, or to deal more broadly with the northwestern quadrant of the United States, or even of North America (See Map). Some courses dealing with the Southwest treat a gulf-centered Southwest, or Spanish colonial borderlands region. Others define the Southwest in terms of historic Mexican territory and current Mexican migration (See Map).

The survey also asked about recent changes in the geographical scope of regional courses. Reflecting the consensus on the definition of the South, only two responses noted changes in the coverage of southern courses. However, there were seven responses relating to western subregions (North $\mathrm{Pa}$ cific, Great Plains, Northwest, Southwest) and ten relating to general West/Frontier courses. Two points stand out. First, there may be a general westward tilt in courses on western American history, with relatively more attention now being given to the Rocky Mountain and Pacific Coast states (5 cases), Hawaii (4 cases), and Alaska (8 cases). Second, there is increasing interest in placing the development of the American West within an international context that crosses the borders with Canada (3 cases) and Mexico (2 cases), or spans the Pacific Ocean (3 cases).

To explore the interpretive and theoretical structuring of individual regional courses, the survey asked whether each course emphasizes certain books as essential to understanding the history and character of the specific region. It also asked whether each course introduces students to key books or theories for understanding the general character and role of regions within the development of the United States. Relatively few respondents made a clear distinction between interpretations of a specific regional history and general interpretations or theories of regionalism and regional change. Indeed, there was substantial overlap between the authors listed for each question (Tables 13, 14). Both for the South and for the West and its subregions, the authors most commonly cited, in response to each question, are the historiographic heroes of previous decades and generations who have framed academic debates: Frederick J. Turner, Walter P. Webb, Herbert E. Bolton, and Henry Nash Smith for the West; C. Vann Woodward, Wilbur Cash, Eugene D. Genovese, and U. B. Phillips for the South. It is important to note for balance, however, that at least one third of the cited authors have published their major work in the 1970s and 1980s.

The converse of sustained attention to a long historiographic heritage is limited interest in current theory and analysis in related disciplines, especially among southern historians. Indeed, one respondent complained that the question about general models of regionalism sounded too much like social science for his/her course. 
Southern historians cited only three books by non-historians-V. O. Key's Southern Politics, Robert Fogel's and Stanley Engerman's Time on the Cross, and John S. Reed's The Enduring South (three citations). ${ }^{20}$ Of these, Southern Politics and Time on the Cross were conceived and developed in historical terms. In addition, southern historians cited a handful of interpretive themes relating to the influence of geography and climate (twice), the role of tradition and legend in cultural development, and models of unbalanced regional growth.

Western historians appear to be more open to other disciplines, citing Merrill Jensen's edited social science symposium, Regionalism in America, Carl Kraenzel's Great Plains in Transition, the work of geographers Carl Sauer and Donald Meinig, regional planner Frank Popper's idea of a continuing twentieth-century frontier, and Edward Spicer's Cycles of Conquest. ${ }^{21}$ Among broad theoretical approaches, four western historians referred to spatial models of economic development, such as staple theory and dependency theory. ${ }^{22}$ Two referred to the importance of natural resource endowment, as mediated and modified by human activity. Two referred to international comparisons of developing resource regions. Seven referred to aspects of group definition or interaction within the larger regional context, with specific reference to ethnohistory, feminist scholarship, and the insights of anthropology.

The survey data confirm a general impression that southern history remains a lively, but relatively self-contained, field. There appears to be continuous generational renewal of faculty as well as strong monographic work, the interpretations of which are incorporated into course content. (Approximately half of the authors listed in Table 13 have published key work in the last twenty years.) At the same time, the field remains set within long-established spatial and conceptual boundaries, with limited attention to other social sciences.

Western history is less settled. Faculty who teach about the West are somewhat older than those who teach about the South. Courses retain an

${ }^{20}$ V.O. Key, Southern Politics in State and Nation (New York, 1949); Robert W. Fogel and Stanley L. Engerman, Time on the Cross: Evidence and Methods-A Supplement (Boston, 1974); John Shelton Reed, The Enduring South: Subcultural Persistence in Mass Society (Lexington, MA, 1972).

${ }^{21}$ Jensen, Regionalism in America; Carl Kraenzel, The Great Plains in Transition (Norman, OK, 1955); Edward H. Spicer, Cycles of Conquest: The Impact of Spain, Mexico, and the United States on the Indians of the Southwest, 1533-1960 (Tucson, 1962); Frank J. Popper, "The Strange Case of the Contemporary American Frontier," Yale Review, 76 (December 1986), 101-21.

${ }^{22}$ Both theories have been "imported" into United States history-the staple theory from work on the development of Canada and dependency theory from analyses of European overseas economic and colonial expansion. 
intense focus on the old, but eminently teachable, ideas of Turner and Webb. At the same time, western history specialists are open to ideas from outside old historiographic boundaries. Many of these theoretical approaches emphasize new ways of looking at the experiences and interactions of different types of westerners. The popularity of southwestern history, with its strong ethnic component, fits within this trend. Other interpretations offer new ways to understand the process of settlement and resource development within a national and international context.

The references among western historians to theories and interpretations from other disciplinies also suggest that the field may be positioned for significant redirection, or revitalization, by a younger cohort of scholars. In particular, western history may take the lead in incorporating the insights of both American cultural studies and regional economic analysis. Western historians who pursue the former route will find themselves sharing ideas about the meaning and sense of place with specialists in literature, the visual arts, landscape architecture, and environmental psychology. Those who follow the latter path will find themselves working with historical sociologists, political economists, and regional planners. In return for new interpretive insights, historians can contribute analytical depth and awareness of variability to cognate disciplines.

Indeed, the variability of regional definition is, itself, evidence of the vitality of the field. Unlike the stable and enduring South, the American West has always been defined in terms of growth and change. Perhaps for this reason, western specialists also seem the most flexible of regional historians in their willingness to entertain alternative regional definitions. The various Wests described for this survey span prairies, deserts, oceans, and national boundaries in ways determined by the categories of analytical interest. By working creatively with the very idea of region and regional identity, western history can contribute to the reestablishment of space and spatial relationships as an essential analytical category for American history. 


\section{Table 1}

GEOGRAPHICAL DISTRIBUTION OF QUESTIONNAIRES SENT AND RETURNED*

\begin{tabular}{lcc}
\hline \hline & $\begin{array}{c}\text { Questionnaires } \\
\text { Sent } \\
(n=500)\end{array}$ & $\begin{array}{c}\text { Questionnaires } \\
\text { Returned } \\
(n=309)\end{array}$ \\
Northeast & 28.8 & 25.6 \\
New England & 9.4 & 8.1 \\
Middle Atlantic & 19.4 & 17.5 \\
South & 29.8 & 28.5 \\
North Central & & 27.5 \\
East N.C. & 25.0 & 18.1 \\
West N.C. & 16.6 & 9.4 \\
West & 8.4 & 18.4 \\
*n percentages & 16.4 & \\
\hline \hline
\end{tabular}


Table 2

PROPORTION OF RESPONDING SCHOOLS OFFERING REGIONAL COURSES

Type of Institution $(\mathrm{n}=307)^{*}$

Public $72 \%$

Private $44 \%$

Type of Degree Offerings $(n=307)^{*}$

Four-year college $34 \%$

Comprehensive master's programs $76 \%$

Comprehensive doctoral programs $68 \%$

Estimated University Enrollment $(\mathrm{n}=295)^{*}$

Under 1000

$38 \%$

1000-499

$43 \%$

5000-9999

$67 \%$

10,000-19,999

$75 \%$

Over 20,000

$69 \%$

Location of School $(n=309)^{*}$

Middle Atlantic

$17 \%$

New England

$36 \%$

East North Central

$45 \%$

West North Central

$76 \%$

South

$83 \%$

West

$86 \%$

Origins of Student Population $(n=293)$

Less than 50 percent in-state

50-90 percent in-state

$63 \%$

More than 90 percent in-state

$63 \%$

* Significant at .005

Table 3

PROPORTION OF RESPONDING SCHOOLS OFFERING REGIONAL COURSES: PUBLIC AND PRIVATE INSTITUTIONS, BY SIZE

\begin{tabular}{ccc}
\hline \hline & Public & Private \\
Enrollment & & \\
Under 5000 & $57 \%$ & $39 \%$ \\
$5000-19,999$ & $74 \%$ & $64 \%$ \\
$20,000+$ & $72 \%$ & $33 \%$ \\
\hline
\end{tabular}


Table 4

FREQUENCY OF COURSE OFFERINGS COVERING SPECIFIC REGIONS, FOR RESPONDING SCHOOLS

\begin{tabular}{lcc}
\hline \hline & $\begin{array}{c}\text { Directly } \\
\text { Reported }\end{array}$ & $\begin{array}{c}\text { Indicated by } \\
\text { Course Titles }\end{array}$ \\
West or Frontier & 130 & 116 \\
South & 112 & 110 \\
Southwest & 26 & 24 \\
Pac. Northwest & 13 & 13 \\
Great Plains & 13 & 10 \\
New England & 15 & 8 \\
Middle West & 8 & 1 \\
Middle Atlantic & 5 & 0 \\
Other & 18 & $10 *$
\end{tabular}

* Applachia (5), North Pacific, Colonial Louisiana, Ozarks, Tennessee Valley, Sunbelt

Table 5

DISTRIBUTION OF REPORTED REGIONAL COURSES

BY INSTITUTIONAL CHARACTERISTICS

Regional Course Coverage

(In Percentage)

\begin{tabular}{lrrrrrrr}
\hline \hline & $W / F$ & $S$ & $S W$ & $P N W$ & $G P$ & $N E$ & Any Reg. \\
GOVERNANCE & 77 & 72 & 73 & 77 & 92 & 64 & 72 \\
Public & 23 & 28 & 27 & 23 & 8 & 36 & 28 \\
Private & & & & & & & \\
DEGREE & & & & & & & \\
OFFERINGS & 27 & 21 & 8 & 31 & 23 & 25 & 23 \\
4-YR & 51 & 39 & 58 & 38 & 54 & 50 & 42 \\
Masters & 32 & 40 & 34 & 31 & 23 & 25 & 35 \\
PHD & & & & & & & \\
& & & & & & & \\
PROPORTION & 16 & 24 & 26 & 0 & 0 & 23 & 23 \\
IN-STATE STUDENTS & & 53 & 52 & 92 & 46 & 77 & 56 \\
$<50 \%$ & 58 & 53 & 22 & 8 & 54 & 0 & 21 \\
50-90\% & 26 & 23 & & & & & \\
>90\% & & & & & & & \\
& & & & & & \\
NUMBER OF & 18 & 19 & 17 & 23 & 15 & 36 & 25 \\
STUDENTS & 62 & 59 & 54 & 62 & 54 & 43 & 50 \\
to 5000 & 20 & 22 & 29 & 15 & 31 & 21 & 25 \\
5-20,000 & & & & & & & \\
20,000+ & & & & & & & \\
\hline
\end{tabular}


Table 6

REGIONAL COURSE OFFERINGS BY INSTITUTIONAL LOCATION

\begin{tabular}{|c|c|c|c|c|c|c|c|}
\hline & $W / F$ & $S$ & $S W$ & $P N W$ & $G P$ & $N E^{1}$ & $N E^{2}$ \\
\hline $\begin{array}{l}\text { Percent of Schools } \\
\text { in Regional Core } \\
\text { Offering Course } \\
\text { on That Region }\end{array}$ & $74 \%$ & $68 \%$ & $41 \%$ & $79 \%$ & $26 \%$ & $32 \%$ & $28 \%$ \\
\hline $\begin{array}{l}\text { Percent of Schools } \\
\text { Outside Regional } \\
\text { Core Offering } \\
\text { Course on That } \\
\text { Region }\end{array}$ & $25 \%$ & $24 \%$ & $3 \%$ & $1 \%$ & $1 \%$ & $2 \%$ & $1 \%$ \\
\hline $\begin{array}{l}\text { Percent of All } \\
\text { Courses on Region } \\
\text { Offered within } \\
\text { Regional Core }\end{array}$ & $62 \%$ & $54 \%$ & $73 \%$ & $85 \%$ & $77 \%$ & $53 /$ & $88 \%$ \\
\hline $\begin{array}{l}\text { Regional Core Def } \\
\text { West: All stat } \\
\text { South: Confec } \\
\text { Southwest: T } \\
\text { Northwest: W } \\
\text { Great Plains: } \\
\text { New England }\end{array}$ & $\begin{array}{l}\text { nitions } \\
\text { es west } \\
\text { erate s } \\
\text { R, NM } \\
\text { A, OR } \\
\text { ND, D } \\
\text { ME, }\end{array}$ & $\begin{array}{l}\text { MIssi } \\
\text { es plus } \\
\text { A, CA } \\
\text { D } \\
\text { NE, K } \\
\text { H, VT, }\end{array}$ & $\begin{array}{l}\text { Ppi Ri } \\
\text { OK, K } \\
\text { OK, } \\
\text { MA, C }\end{array}$ & $\begin{array}{l}\mathrm{WV}, \mathrm{I} \\
\mathrm{X}, \mathrm{NM} \\
\mathrm{RI}\end{array}$ & $\begin{array}{l}\mathrm{ID}, \mathrm{DC} \\
\mathrm{CO},\end{array}$ & $\begin{array}{l}\text { and DE } \\
\mathrm{Y}, \mathrm{MT}\end{array}$ & \\
\hline $\begin{array}{l}\mathrm{NE}^{1}: \text { Courses are } \\
\mathrm{NE}^{2}: \text { Courses as id }\end{array}$ & $\begin{array}{l}\text { eported } \\
\text { entified }\end{array}$ & $\begin{array}{l}\text { y depa } \\
\text { y titles }\end{array}$ & ments & & & & \\
\hline
\end{tabular}

Table 7

STUDENT INTEREST IN REGIONAL COURSES

\begin{tabular}{lccc}
\hline \hline & $\begin{array}{c}\text { South } \\
(n=149)\end{array}$ & $\begin{array}{c}\text { West } \\
(n=160)\end{array}$ & $\begin{array}{c}\text { Other } \\
(n=93)\end{array}$ \\
$\begin{array}{l}\text { Current Interest Compared } \\
\text { with Ten Yrs Previous }\end{array}$ & & \\
Greater & $18 \%$ & $22 \%$ & $28 \%$ \\
Same & $68 \%$ & $59 \%$ & $62 \%$ \\
Less & $13 \%$ & $19 \%$ & $10 \%$ \\
& & \\
& Chi square $=7.31$, Prob. $=.12$ & \\
\hline
\end{tabular}




\begin{tabular}{lccc}
\hline \multicolumn{3}{c}{ Table 8} \\
CONTINUITY IN REGIONAL COURSE OFFERINGS \\
\hline $\begin{aligned} \text { South } \\
(n=165)\end{aligned}$ & $\begin{array}{r}\text { West } \\
(n=168)\end{array}$ & $\begin{array}{c}\text { Other } \\
(n=94)\end{array}$ \\
Years Present or Similar & & & \\
Course Offered & $9 \%$ & $8 \%$ & $18 \%$ \\
1-5 Years & $21 \%$ & $6 \%$ & $26 \%$ \\
5-10 Years & $70 \%$ & $86 \%$ & $53 \%$ \\
$111+$ Years & &
\end{tabular}

Table 9

CONTINUITY IN REGIONAL HISTORY INSTRUCTION

\begin{tabular}{lccc}
\hline \hline & $\begin{array}{c}\text { South } \\
(n=161)\end{array}$ & $\begin{array}{c}\text { West } \\
(n=162)\end{array}$ & $\begin{array}{c}\text { Southwest } \\
(n=91)\end{array}$ \\
Years Course Taught by & & & \\
Same Instructor & $27 \%$ & $28 \%$ & $37 \%$ \\
1-5 Years & $24 \%$ & $15 \%$ & $25 \%$ \\
5-10 Years & $48 \%$ & $57 \%$ & $37 \%$ \\
111+ Years & & \\
& Chi square $=10.78$, Prob. $=.05$ \\
\hline
\end{tabular}

\begin{tabular}{|c|c|c|c|}
\hline \multicolumn{4}{|c|}{$\begin{array}{c}\text { Table } 10 \\
\text { REGIONAL HISTORY INSTRUCTORS } \\
\text { BY AGE AND SPECIALIZATION }\end{array}$} \\
\hline & South & West & Other \\
\hline & $(n=161)$ & $(n=163)$ & $(n=94)$ \\
\hline \multicolumn{4}{|l|}{ Age in 1988} \\
\hline 56 or more & $22 \%$ & $34 \%$ & $23 \%$ \\
\hline $40-55$ & $63 \%$ & $53 \%$ & $64 \%$ \\
\hline Under 40 & $15 \%$ & $13 \%$ & $13 \%$ \\
\hline \multicolumn{4}{|c|}{ Chi square $=6.91$, Prob. $=.15$} \\
\hline
\end{tabular}


Table 11

REGIONAL HISTORIANS BY AGE AND ACADEMIC GENERATION (South, West, Southwest Specialists)

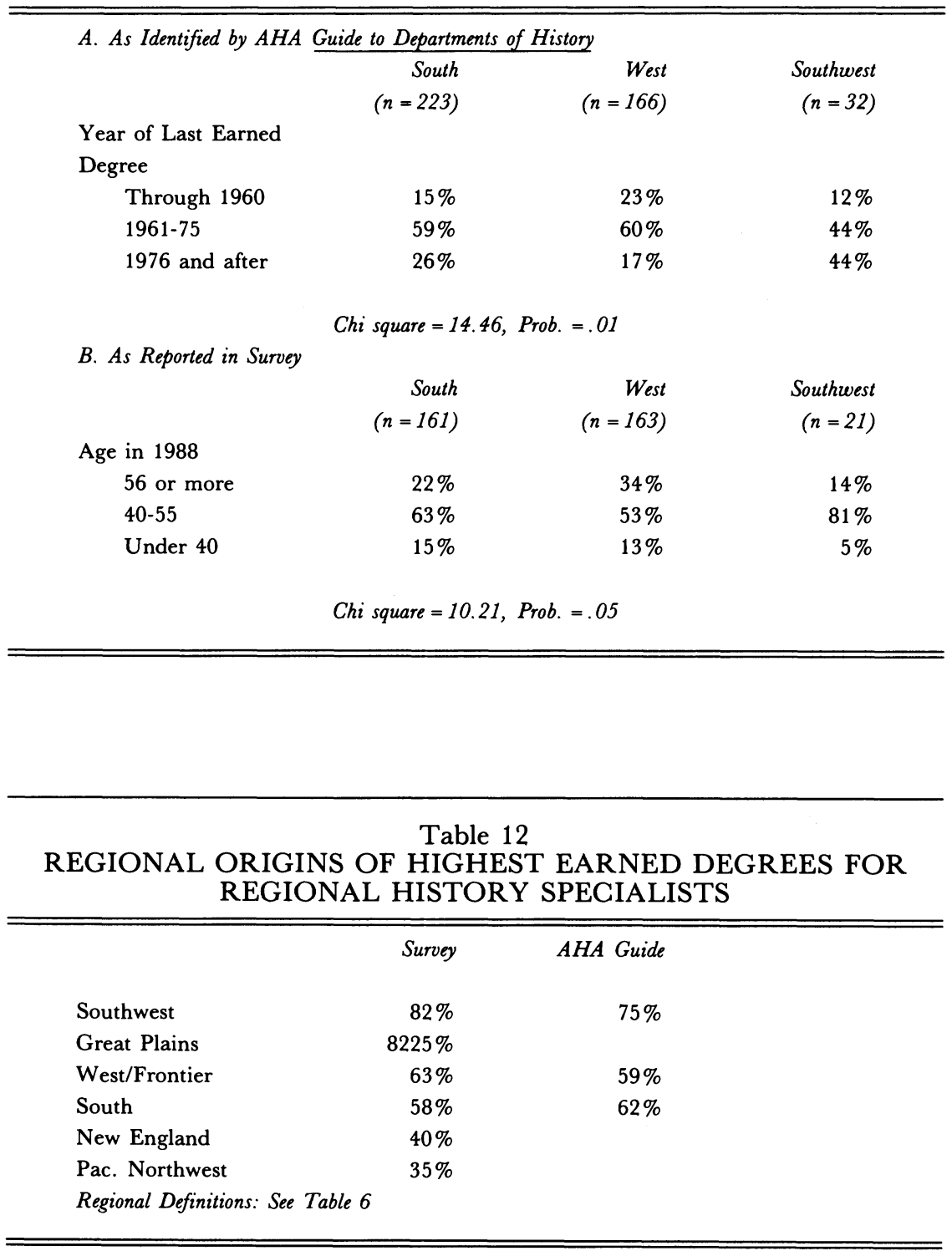




\section{Table 13 \\ SOUTHERN HISTORY COURSES \\ FREQUENCY OF CITATION OF KEY AUTHORS}

\begin{tabular}{llll}
\hline \hline & $(1)$ & $(2)$ & \\
C. Vann Woodward & 20 & 7 & 27 \\
Wilbur Cash & 13 & 2 & 15 \\
Eugene Genovese & 10 & 2 & 12 \\
Clement Eaton & 8 & 1 & 9 \\
U.B. Phillips & 4 & 4 & 8 \\
Kenneth Stampp & 4 & & 4 \\
Edmund Morgan & 4 & & 4 \\
George Tindall & 4 & & 4 \\
B. Wyatt-Brown & 3 & 1 & 4 \\
Joel Williamson & 3 & & 3 \\
J. H. Franklin & 2 & 1 & 3 \\
Paul Gaston & 2 & 1 & 3 \\
Frank Owsley & 2 & 1 & 3 \\
David Potter & 2 & 2 & 2 \\
John S. Reed & 1 & & 2 \\
I. A. Newby & 2 & & 2 \\
David Goldfield & 2 & & 2 \\
John McCardell & 1 & & \\
Carl Bridenbaugh & & & \\
& & & \\
(1) Authors of books or articles cited as essential for understanding history and character of \\
South. & & & \\
(2) Authors cited as important for theoretical understanding of general character and role of \\
regions within growth of the United States. & & & \\
& & & \\
\hline \hline
\end{tabular}


